\title{
APRESENTAÇÃO DO DOSSIÊ "Precarização do Trabalho Docente"
}

\author{
PRESENTATION OF THE DOSSIER \\ "Precarization of Teaching Work"
}

Jussara Marques de Macedo

Miriam Morelli Lima

A partir dos anos de 1990 o Brasil passa a implementar a contrarreforma da educação pautado nas orientações da Organização das Nações Unidas para a Educação, a Ciência e a Cultura (UNESCO) e outros organismos nacionais, materializados principalmente na Declaração Mundial de Educação para Todos: satisfação das necessidades básicas de aprendizagem (1990) e no documento Educação para Todos: o compromisso de Dakar (2000).

Todas as orientações estão ligadas aos pressupostos da "sociedade do conhecimento" que deram origem ao gerencialimo e, consequentemente, à "Nova Gestão Pública" que no Brasil foi confirmada no Plano Diretor da Reforma do Aparelho do Estado (1995), contribuindo assim, para que se ajustasse também a gestão dos sistemas de ensino e das escolas ao modelo gerencial.

Nesse contexto, foram alteradas as condições para realização do trabalho docente na educação básica, passando-se a exigir desse trabalhador novas competências que vão desde a preparação do Projeto Pedagógico - e não mais Projeto Político Pedagógico - até as funções da gestão do seu próprio trabalho objetivando o alcance de metas com enfoque nos resultados. Tendo em vista o docente de novo tipo, a partir da Lei 9.394/96 passou a ser delineada uma política de formação para o trabalho docente com vistas a moldar esse trabalhador ao modo flexibilizado exigido pelo capital.

Nesse contexto de precarização do trabalho docente, que se inicia, muitas vezes ainda nos processos de formação inicial, que nasceu a ideia de organização desse Dossiê. Mas sem sombra de dúvidas, nos motivou o fato de lançarmo-nos ao 
debate que, algumas vezes, tem sido colocado à margem por aqueles que engrossam a defesa da valorização exacerbada em torno da valorização do conhecimento tácito do professor, e da prática em detrimento da teoria. Estes fatos têm contribuído diretamente para a implantação de cursos aligeirados e fragmentados em nível superior com sua origem "além-mar" que deram/dão sustentabilidade às iniciativas de criação da Universidade Aberta do Brasil (UAB) e de cursos de metrados profissionalizantes que tomam conta das nossas universidades públicas, baseados principalmente na ideia do savoir faire. Algumas destas instituições com tradição na formação docente, e que por longos anos mantiveram-se no propósito de garantir a tríade ensino, pesquisa e extensão na formação, certos de que esse é o caminho para a formação de docentes autônomos e emancipados capazes de se articularem em torno dos interesses da classe trabalhadora com olhar voltado para a superação da sociedade de classes, com homens e mulheres comprometidos com seus semelhantes e não apenas consigo mesmo, como temos observados em comportamentos de alguns que compõem a "direita" e, lamentavelmente, também da "esquerda".

A parir dessas reflexões convidamos à leitura do Dossiê Precarização do Trabalho Docente, certos de que os artigos servirão não como cartilhas doutrinárias sobre o tema, mas que nos dará possibilidades de refletirmos sobre essa temática tão cara a nós docentes que atuamos em diferentes níveis de ensino no Brasil ou fora dele. Temos convicção de que não iniciaremos aqui um debate inédito, mas buscamos lançar luz sobre algumas questões que, embora não respondidas nesse Dossiê, trarão à baila a necessidade de nos mantermos em determinados caminhos que nem sempre são os mais valorizados no meio acadêmico.

Nessa direção o primeiro artigo Fundamentos Teóricos e Metodológicos da Precarização do Trabalho Docente que inicia o Dossiê analisa o processo de precarização do trabalho docente no Brasil a partir dos anos 1990 e o faz à luz do processo de reestruturação produtiva fundamentada nas teorias da "sociedade do conhecimento" que possibilitou o gerencialismo e a lógica da "Nova Gestão Pública". Tais fundamentações contribuíram para precarização do trabalho docente que, do ponto de vista das autoras, já tem na formação, também precarizada, a ideia de um docente que adquira competências necessárias ao trabalhador do conhecimento. Neste sentido, destaca que a formação se distancia cada vez mais da perspectiva da formação para a emancipação humana.

O segundo artigo Trabalho Docente no Contexto do Retrocesso do Retrocesso os autores apresentam de forma clara o processo de desmonte da educação pública 
brasileira que intensifica a "expropriação", a "coisificação" e a "precarização do trabalho docente". Tomaram como referência as notícias recentes oriundas do aparato do Estado e da sociedade civil para melhor compreender as mudanças recentes na educação do país.

0 terceiro artigo Mais Trabalho em Busca de mais Salário: mercantilização do trabalho docente na UFPA os autores analisam como a necessidade de complementação salarial tem contribuído para o processo de "intensificação" e "mercantilização do trabalho" na Universidade Federal do Pará. Parte do princípio de que o trabalho na universidade tem sido definido "em função da política de ampliação do espaço privado-mercantil e da expansão de cursos e matrículas" sem, contudo, aumentar o financiamento e a contratação de recursos humanos. A conclusão é que os docentes universitários que buscam melhores condições salariais têm contribuído para o processo de "mais-trabalho" e a "mercantilização da universidade pública".

No quarto artigo Expansão da Educação, Intensificação e Proletarização do Trabalho Docente em Portugal no Século XXI o autor, analisa o processo de procura por educação em Portugal a partir de 1974, demonstrando seu decréscimo a partir do século XXI, principalmente pelo baixo índice de natalidade, inclusive no ensino superior, a partir de 2008. Nesse contexto, analisa as relações entre o aumento do número de docentes, a procura por educação e as medidas de austeridade implementadas pelo Estado. A conclusão é que as medidas tomadas pelo governo em relação ao trabalho docente contribuíram para a "intensificação e proletarização do trabalho docente".

No quinto artigo La Precarización del Trabajo Docente en el Sistema Educacional Chileno as autoras objetivam analisar as condições do trabalho docente no Chile com base nas políticas neoliberais que foram postas em prática no país a partir dos anos de 1980. 0 artigo é resultado da análise de documentos legais, da análise de artigos oriundos dos movimentos docentes e da Lei da Carreira Docente de 2016 posta em prática pelo governo. A conclusão é que embora a Lei atenda minimamente algumas reivindicações dos docentes ela acaba pondo em prática a lógica da avaliação e da certificação periódica que impõe aos trabalhadores docentes maior carga de trabalho.

No sexto artigo Trabalho Docente em Tempos Neoliberais: implicações para a formação do Serviço Social as autoras partem do pressuposto de que as transformações no ensino superior que impactaram a formação dos assistentes sociais vão interferir diretamente no projeto ético político desse profissional. A pesquisa bibliográfica possibilitou concluir que a transferência de recursos 
públicos para as instituições privadas levou à massificação desse grau de ensino desqualificando e precarizando o trabalho e a formação docente nesse grau de ensino.

No sétimo artigo Trabalho Docente Feminizado: as percepções produzidas sobre a profissão e as influências na organização e valorização do trabalho no magistério as autoras tomam por base para análise do trabalho docente as implicações de seu processo de feminização. Objetiva "compreender em que medida a feminização do magistério incide sobre as percepções produzidas sobre essa profissão e a sua (des)valorização". Partem da ideia de que a feminização do magistério é resultado do processo histórico e por isso sofre influência da política, da economia e da cultura. Concluem que, se por um lado não devemos "culpabilizar as mulheres (nem os homens) pela desvalorização do trabalho docente" por outro, o que compõe o imaginário acerca do magistério e do trabalho docente é resultado de como se deu o processo de (des)valorização docente em nosso país.

No oitavo artigo Trabalho Docente na Educação Infantil os autores analisam o significado do trabalho docente na educação infantil e os desafios enfrentados nesta etapa da educação. Objetivou analisar o trabalho docente nesse segmento de ensino ultrapassando a ideia da vocação dos docentes que nele atuam. Os resultados apontam que a formação desse docente deve ser continuada e ultrapassar os limites da formação prática, presente na concepção hegemônica de formação.

Por fim, no último e nono artigo As Lutas Sociais, Sindicais e Políticas do Ensino Privado de Osasco e Região: a experiência do SIMPROSASCO (1985-1992) os autores fundamentam-se na perspectiva histórico educacional para analisar o Sindicato de Professores de Osasco e Região (SIMPROSASCO), no período de 1985, ano de sua criação, a 1992 por expressar um “divisor de águas" na organização da educação. Teve por objetivo reconstruir a memória do sindicato e suas formas de luta. 0 resultado aponta para o fato de que o SIMPROOSASCO é representativo da categoria e que por isso necessita ter visibilidade no contexto da educação brasileira já que é representativo no que e refere ao "associativismo e sindicalismo dos trabalhadores em educação do ensino privado".

A partir de diferentes referenciais, metodologias e abordando diferentes aspectos, os artigos apresentados neste Dossiê, têm como objeto o trabalho docente, analisados dentro da atual conjuntura que altera não só as condições do trabalho docente, mas também as formas como se realiza. Em seu conjunto, os artigos evidenciam que o trabalho docente sofre as consequências da 
contrarreforma do Estado, de modo especial, da "Nova Gestão Pública", pautada pela competitividade, pela precarização e pela intensificação do trabalho docente. É neste sentido, que este Dossiê busca refletir à luz de diferentes quadros teóricometodológicos, uma forma de fundamentar importantes análises que se fazem cada vez mais necessária para compreender as mudanças que se impõem sobre o trabalho docente na atualidade.

Lisboa, outono de 2017. Rio de Janeiro, primavera de 2017 
RTPS - Rev. Trabalho, Política e Sociedade, Vol. II, no 03, p. 213-218, jul-dez/2017. 